\title{
Influence of productive resources on bean production in male- and female-headed households in selected bean corridors of Kenya
}

\author{
Scolastica Wambua ${ }^{*}$, Eliud Birachi ${ }^{2}$, Ann Gichangi ${ }^{1}$, Justus Kavoi ${ }^{1}$, Jemimah Njuki ${ }^{3}$, Mercy Mutua², \\ Michael Ugen ${ }^{4}$ and David Karanja ${ }^{1}$
}

\begin{abstract}
Background: Gender-related constraints reflect gender inequalities in access to resources and development opportunities. Access to productive assets is a major issue in the gender empowerment discourse. Despite the significant roles women play in agriculture and food security in many developing countries, they continue to have a poorer command over a range of productive resources, including education, land, information and financial resources compared to their men counterparts. The purpose of the study was to establish the effect of access and control of productive resources on bean production.

Results: Data collected from 412 households in the major bean corridors of Kenya (Homa Bay, Machakos, Bomet and Narok counties) were used to explain the importance of access to productive resources and income use in determining the quantity of beans produced by households. We found that the sex of the respondent was significantly correlated with bean production, with female-headed households producing less beans than the male-headed ones $(p=0.0 .08)$. With regard to access and control of productive resources, households with more agricultural incomes and those who put a larger proportion of their land to agriculture produced more beans $(p=0.008 ; p=0.000$, respectively). Access and use of fertilized and hired labour was also highly significant. When assessing decision making on the use of income from bean sales was considered, households where the female spouse made decisions produced less beans compared to those that had the male household head being the main decision maker $(p=0.011)$.
\end{abstract}

Conclusions: We concluded that access and control of productive assets are important in determining the quantity of beans produced at household level. There is a need therefore to come up with interventions which will benefit all the households but are targeted to the needs of the male- and female-headed households.

Keywords: Gender, Access, Control, Productive resources, Beans, Income

\section{Background}

In Kenya, common bean (Phaseolus vulgaris L.) is the most significant pulse crop with maize being second as a food crop [5]. Beans are a source of cheap dietary protein and thus affordable by most poor households. The crop has multiple uses, the major ones being food and source of income. Access to productive capital such as land, fertilizers, farm equipment, education, technology

\footnotetext{
*Correspondence: scolasticawambua@yahoo.com

${ }^{1}$ Kenya Agricultural and Livestock Research Organization (KALRO), P.O Box 57811-00200, Nairobi, Kenya

Full list of author information is available at the end of the article
}

and financial services is a key element of agricultural productivity [11]. Though agriculture is important to women, they have less access to the resources and services required for agricultural production. It is important to understand the gender differences in access and control of productive resources and how this affects bean production. This paper therefore assessed the effects of access and control of productive resources on bean production for male- and female-headed households. The resources studied here were land, seed, farm equipment and fertilizers. Access to new technology is crucial in maintaining and improving agricultural productivity. 
There gender gaps exist for a wide range of agricultural technologies, including machinery and tools, improved crop varieties and animal breeds, fertilizers, pest and disease control measures and management techniques. "A number of constraints, including the gender gaps described above, lead to gender inequalities in access to and adoption of new technologies, as well as in the use of purchased inputs and existing technologies" [11]. The use of bought inputs depends on the availability of assets such as land, credit, education and labour, all of which happen to be more constrained for female-headed households than for male-headed households. According to Blackden et al., adoption of improved technologies for example crop varieties is positively correlated with education but is also dependent on time constraints. In an activity with long turnaround periods, such as agriculture, working capital is required for purchasing inputs such as chemicals, fertilizers and improved seeds; however, as discussed above, women face more obstacles relative to men in their access to credit. Women's lesser ability to absorb risk may constrain adoption of improved bean varieties and inputs.

Growing populations and declining agricultural productivity are leaving millions without secure sources of food; hence, there is the need to upsurge food production. Advances in food production are constrained by the "invisibility factor" in other words, by women's major but largely unrecognized roles in agriculture. According to Palacios-Lopez et al. [13], average labour contribution to crop production in six Sub-Saharan countries was estimated at $40 \%$ instead of the $80 \%$ reported by FAO, though differences exist across countries. The female labour share amounts to slightly more than $50 \%$ in Uganda, Tanzania and Malawi (56, 52 and 52\%, respectively), which is also consistent with the slightly higher share of women in these populations (52, 53 and 51\%, respectively) [9]. Failure to recognize this contribution is costly. This results in imprudent policies and programs, forgone agricultural production and associated income flows, higher levels of poverty, and food and nutrition insecurity [20]. In sub-Saharan Africa, it has been estimated that agricultural productivity could increase by up to 20 per cent if women's access to such resources as land, improved seed and fertilizer was equivalent to men's [7]. However, women still face serious constraints in obtaining essential support for most productive resources, such as land, fertilizer, knowledge, infrastructure and market. For households that rely on agriculture for their livelihoods, land is the most critical household asset [8]. It is a basic requirement for farming, and control over it is tantamount to wealth, status and power in many areas. Strengthening women's access to and control over land is an imperative means of raising their status and influence within households and communities. Improving women's access to land and security of tenure has direct effects on farm productivity and can also have important implications for improving household welfare. Allendorf [1] found out that strengthening land ownership by women in Nepal was linked to better health outcomes for children. According to a SNV brief [15], women farmers often have to negotiate or even pay to access productive resources, which are mainly owned by men or controlled by male-dominated authorities.

\section{Methodology \\ Description of study areas}

Study areas were Bomet, Homa Bay, Machakos and Narok Counties, Kenya. These counties form one of the bean corridors in Kenya. A corridor is an area of bean intensification characterized by flows of product from production to consumption in specific bean intensification zones where significant bean activities take place including production, distribution and consumption. The corridor approach is motivated by existence of inefficiencies in production and marketing of bean. This is shown by lack of sufficient tradable volumes of right bean grain to attract major off-takers and reluctance by bean producers and buyers to engage in longer-term contract for supply of bean. The approach is meant to bring about more efficient bean product movement, by reducing the costs of production and improving marketing to enhance incomes of households and other actors participating in the value chain [14]. Bomet County is among the nine counties in the Rift Valley region. It lies between $0039^{\prime}$ and $1002^{\prime}$ South of the Equator and between longitudes $35^{\circ \prime}$ and $32^{\circ \prime}$ East of prime meridian. Agriculture is the backbone of the county with tea farming and dairy production leading in the region. Some of the crops grown in the county include beans, Irish potatoes, millet, cabbages, onions, bananas and pineapples. In Bomet, women form the bulk of the work force in the tea growing areas mostly in weeding and tea picking. According to Kalenjin culture, women do not own land and they also do not make decisions, and if so, they must consult their spouses [12]. Homa Bay County lies between latitude $0^{\circ} 15^{\prime}$ South and $0^{\circ} 52^{\prime}$ South and between longitudes $34^{\circ}$ East and $35^{\circ}$ East. The major food crops grown in the area include sorghum, millet, maize, beans, kales, sweet potatoes and cow peas. The vast majority $(80 \%)$ of the farmers produce maize and beans mainly because they are considered the staple foods of the county. Narok County is situated in the South Rift Valley bordering the Republic of Tanzania to the South, Kisii, Migori, Nyamira and Bomet counties to the West, Nakuru County to the North and Kajiado County to the East. The county lies between latitudes $0^{\circ} 50^{\prime}$ and $1^{\circ} 50^{\prime}$ South and longitude $35^{\circ} 28^{\prime}$ and $36^{\circ} 25^{\prime}$ 
East. Narok County is occupied by the Maasai community. In Maasai culture, women perform many household chores including constructing huts, fetching water, feeding livestock, gathering firewood, milking, cooking and caring for children and the old. Although they do not own any property, since everything belongs to the man, husbands apportion a number of cows, sheep and goats to them for which they take charge of the products such as milk, butter, meat and skin. Machakos County covers an area of $6208.2 \mathrm{~km}^{2}$ with most of it being semi-arid. It lies between latitudes $0^{\circ} 45^{\prime}$ South and $1^{\circ} 31^{\prime}$ South and longitudes $36^{\circ} 45^{\prime}$ East and $37^{\circ} 45^{\prime}$ East. Machakos County is mainly occupied by the Kamaba community whose culture is not as strong, and women participate in decision making and even own land. Majority of the women are also literate.

\section{Sampling procedures and sample size}

The survey adopted a multi-stage sampling technique from county, sub-county, ward, location, sub-location and then villages. In the four counties of Bomet, Homa Bay, Machakos and Narok, a list of bean-producing subcounties was obtained and two wards randomly selected, with assistance from both the local administration and Ministry of Agriculture extension staff. This formed the sampling frame from which the desired sample size of 440 households was randomly drawn in the second stage at the ward level. The households were proportionately spread across the four counties comprising 70 respondents ( $74 \%$ male-headed, $24 \%$ female-headed) from Bomet, 238 respondents (70\% male-headed, 30\% female-headed) from Homa Bay, 61 (92\% male-headed, $8 \%$ female-headed) from Machakos and 71 (86\% maleheaded, 14\% female-headed) from Narok. Homa Bay County had more bean farmers than the other three Counties due to its volumes of bean produced.

\section{Data collection method}

Data were collected by use of questionnaires on tablets via computer-assisted personal interviewing (CAPI) method. This helped reduce errors by enumerators and also avoided missing data; hence, all questions in the questionnaire were answered. Both husband and wife in the household answered certain sections of the questionnaire, where applicable. Questions answered by both husband and wife included: variety preferences, division of labour, decision making, ownership of assets. The questionnaire collected data on demographic and farm characteristics, household incomes, livestock ownership, farm equipment ownership and decision making.

\section{Data analytical technique}

Stata and SPSS packages were used in data analysis. Data were presented by way of means, frequencies, and proportions and cross-tabulations. A multiple regression model was used to determine the effects of access and control of productive resources and household income on quantities of beans produced by households. This was presented as follows;

$$
Y_{i}=a+b x_{1+} b x_{2}+\cdots+b x_{n}+e_{i} .
$$

where $Y_{i}=$ quantity of beans produced in households, $X_{1}=$ sex of respondent, $X_{2}=$ literacy level of household head, $X_{3}=$ access and use of fertilizer, $X_{4}=$ use of pesticides, $X_{5}=$ use of hired labour, $X_{6}=$ annual household income, and $X_{7}=$ proportion of land allocated for bean production.

\section{Results and discussion}

This section describes the data used and discusses results from the study.

\section{Demographic characteristics of households}

Table 1 presents selected household demographics. Over $70 \%$ of the households in all the counties were headed by men. Machakos County had the lowest number of households headed by women (8\%) followed by Narok (14\%) and Bomet (16\%). Homa Bay had the highest femaleheaded households (30\%), and Homa Bay also had the highest number of widows compared to the other counties. The mean age for farmers ranged from 41 years in Narok County to 58 years in Machakos County. Age of

Table 1 Demographic characteristics of respondents

\begin{tabular}{|c|c|c|c|c|c|c|c|c|c|c|c|}
\hline \multirow[t]{2}{*}{ County } & \multirow[t]{2}{*}{$\begin{array}{l}\text { Mean age } \\
\text { (years) }\end{array}$} & \multicolumn{2}{|c|}{$\begin{array}{l}\text { Sex of } H / \text { head } \\
(\%)\end{array}$} & \multicolumn{3}{|c|}{ Marital status } & \multicolumn{5}{|c|}{ Educational level (\%) } \\
\hline & & Male & Female & Married & Single & Widowed & Non & Primary & Secondary & Diploma & University \\
\hline Bomet $(N=70)$ & 46 & 74 & 26 & 89 & 1 & 10 & 10 & 29 & 47 & 14 & - \\
\hline $\operatorname{Narok}(N=70)$ & 41 & 86 & 14 & 86 & 7 & 7 & 10 & 39 & 37 & 11 & 3 \\
\hline Machakos $(N=60)$ & 58 & 92 & 8 & 92 & 2 & 6.7 & - & 27 & 57 & 15 & 2 \\
\hline Homa Bay $(N=228)$ & 50 & 70 & 30 & 77 & - & 23 & 6 & 57 & 28 & 7 & 2 \\
\hline
\end{tabular}


farmers could affect productivity and access to productive resources negatively or positively. In a study by Wiredu et al. [19] on rice cultivation in Ghana, age had positive effect on yield meaning experience in rice cultivation implies accumulated knowledge in rice production. This study showed that the more aged the household head was, the more farm yield was realized. Thamaga-Chitja et al. [17] showed that older household heads had greater access to resources than households headed by younger members, which thus could afford to facilitate production on the farm. Majority of the farmers in all the four counties were literate, and this could have affected access to productive resources. In Vihiga District in Kenya, Waithaka et al. [18] noted the significance of increased education level of the household head on the increased amount of fertilizer used, presumably arising from a better understanding of the usefulness of fertilizers, and it may also imply better crop management. This was echoed by Ariga et al. [2] who found that the level of education has a significant effect on fertilizer use.

Table 2 presents the total land size holding and by sex of household head in the different counties. Narok County had the biggest sizes of land held by households (7 ha), while Homa Bay had the smallest (1.3 ha). Maleheaded households owned slightly bigger sizes of land than the female-headed ones. Narok County is known for cash crop farming, especially for wheat and maize. Maize is mostly produced in Transmara sub-counties where data collection was done. In all the counties, all the households grew beans in 2 or 3 different plots either at home or far away. In Narok beans were grown as pure stand and mainly for the market while in the other three counties, beans were intercropped and were grown for both consumption and market. This means that Narok could be targeted for commercial production of beans for the precooked bean industry. Beans take approximately $2 \mathrm{~h}$ to boil, but a precooked bean product will take $15 \mathrm{~min}$ to boil and be ready for serving. This product will be dried and packed in different sizes and targets career men, women and the youth in urban areas who would like to consume beans but do not have the time to prepare and cook beans. With growing populations in urban areas, this product will come in handy as nutrition security. Common bean is a major source of protein, and majority of Kenyans are embracing healthy to avoid lifestyle diseases caused by poor eating habits. Farmers in other counties could be encouraged to increase sizes of land under beans by also growing beans under pure stand for commercial purposes. The average land size owned by women seems slightly bigger than that of men, but this is because only $8 \%$ of households were headed by females. This could mean higher productivity and improved access to productive resources because they control land use.

\section{Annual income from crops and livestock per household}

Households in Bomet and Machakos earned more annual incomes from livestock than all the other counties (USD 1050 and 950), respectively (Fig. 1). It was expected that Narok would have higher incomes from livestock, but this was not the case. This could be explained by the fact that although the residents have big number of livestock, they do not sell frequently due to their cultural belief that the more cattle and sheep you have, the wealthier you are. Bomet County also had a substantial number of dairy cattle, resulting in higher milk sales which contributed to high livestock income. Mua hills in Machakos County

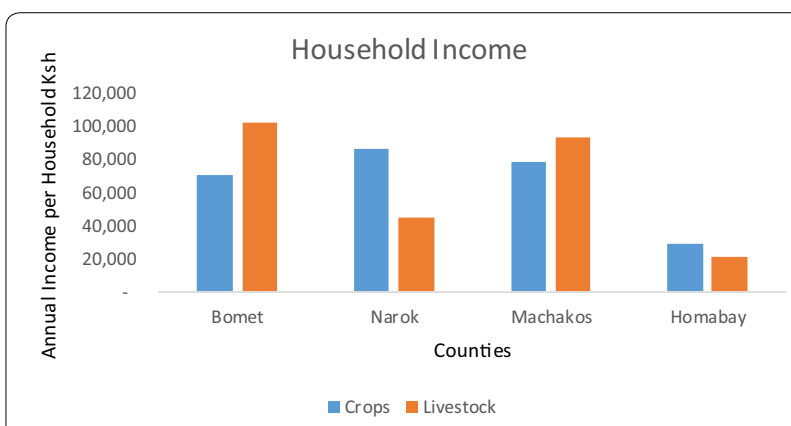

Fig. 1 Annual household income

Table 2 Size of land and proportion under crops

\begin{tabular}{|c|c|c|c|c|c|}
\hline \multirow[t]{3}{*}{ County } & \multicolumn{5}{|l|}{ Land allocation } \\
\hline & \multirow[t]{2}{*}{$\begin{array}{l}\text { Size of total land holding } \\
\text { (ha) }\end{array}$} & \multirow[t]{2}{*}{$\begin{array}{l}\text { Proportion of land } \\
\text { is under crops (ha) }\end{array}$} & \multirow[t]{2}{*}{$\begin{array}{l}\text { Plots with crops last season } \\
\text { (2014B) }\end{array}$} & \multicolumn{2}{|c|}{$\begin{array}{l}\text { Average land size owned } \\
\text { (ha) }\end{array}$} \\
\hline & & & & Men & Women \\
\hline Bomet & 2 & 0.8 & 2 & 1.8 & 3.0 \\
\hline Narok & 6.7 & 1.6 & 2 & 7.0 & 4.8 \\
\hline Machakos & 3.8 & 1.9 & 3 & 4.0 & 4.2 \\
\hline Homa Bay & 1.3 & 1.1 & 2 & 1.5 & 1.1 \\
\hline
\end{tabular}


receive high rainfall, which hence could have contributed to higher incomes from crop and livestock production. Homa Bay had the lowest income from both crops and livestock (USD 300 and 200, respectively); this could be attributed to the fact most of the households there are female-headed caused by death of husbands due to HIV. Homa Bay County has the highest HIV prevalence rate in Kenya. High household incomes could lead to increased bean production because farmers are able to use the recommended quantities of inputs, e.g. fertilizers, herbicides, labour for weeding, chemicals and proper storage.

\section{Farm input use in households per county}

Bomet and Narok had the highest number of households using fertilizers and field pesticides, while Homa Bay had the lowest with $8 \%$ of farmers applying fertilizers and none applying field pesticides. In Bomet, $71 \%$ of maleheaded households and $78 \%$ of female-headed households used fertilizers, while in Narok County $71 \%$ of male-headed households applied fertilizers on the farms compared to $56 \%$ of households headed by females.

In Machakos County, female-headed households did not use fertilizers $(0 \%)$ and storage pesticides $(0 \%)$ completely. This could be explained by the fact that the area is semi-arid and sources of income are limited, so women cannot afford fertilizers and pesticides. The other explanation for the low input use even for maleheaded households in the county could be that beans are grown for subsistence purposes, so farmers possibly do not see the importance of investing so much in the crop. The scenario was almost the same in Homa Bay County whereby both households did not use fungicides and field pesticides completely. This could be due to the warm weather in both counties as compared to the cold and chilly weather in Bomet and high areas of Narok where this study was carried out. Diseases like halo blight, bean anthracnose and leaf rust are prevalent in cool areas with heavy rainfall [6]. In all counties, herbicide, irrigation and manure use were very low or not there completely. The issue of herbicides use could be explained by the fact that most bean farmers are small holders and use manual weeding in their farms using family labour mostly. Due to the fact that bean is viewed as a food security crop, farmers do not irrigate as compared to horticulture crops which farmers view as high value crops. Low use of fertilizers $(32 \%)$ and manure $(0 \%)$ could lead to low productivity, while low use of storage pesticides (14\%) could explain the high post-harvest losses farmers incur.

\section{Farm equipment ownership by sex of household head}

Table 3 presents ownership of farm equipment by sex of household head. Results show more male-headed households owned weighing scale (9\%), knapsack sprayer (43\%)
Table 3 Farmer equipment ownership by sex of household

\begin{tabular}{llll}
\hline Sex of HH & \multicolumn{2}{l}{ Farm equipment ownership } \\
\cline { 2 - 4 } & Weighing scale & $\begin{array}{l}\text { Knapsack } \\
\text { sprayer }\end{array}$ & Ox plough \\
\hline Male (\%) & 9 & 43 & 52 \\
Female (\%) & 3 & 24 & 25 \\
sig & 0.098 & 0.000 & 0.003 \\
\hline
\end{tabular}

and an ox plough (52\%). All these are statistically significant through a Chi-square test. Majority of small holder farmers in these bean-producing areas use ox ploughs to plough and weed their farms. Ownership of an ox plough could have an implication on time of ploughing and planting and eventually quantity harvested. Majority of farmers without ox ploughs tend to plough late because they borrow from their relatives or friends who have to prepare their land first. If rainfall is limited, only the early planters get some harvest. Ownership of a knapsack sprayer means that the farmer sprays his crops against pests which could have a positive effect on yields harvested. For a household, to own a weighing scale could mean that they weigh their produce before selling, hence which cannot be misinformed by the buyers. Cost of equipment could explain the low percentage of ownership of weighing scales. Few female-headed households own farm equipment due to the cost of purchasing, and this could affect negatively their crop productivity. For these households, the implication is that they will plant late, cultivate less land and will not protect their crop from crops and diseases, resulting in low yields.

\section{Effects of access to productive resources on bean production}

Table 4 shows a regression analysis which was used to determine variables that influenced bean production. The variables used were sex of respondent, access to improved seed, annual income from crop farming, proportion of land use and number of market information sources. Results show that the sex of the respondent was slightly correlated with bean production, with femaleheaded households producing less beans than the maleheaded households $(p=0.089)$. This could be attributed to the fact that male-headed households tend to have more access and control of key productive resources like land and inputs.

Regarding access and control of productive resources, households who applied fertilizers produced more beans $(p=0.003)$. Utilization of hired labour was highly significant, implying that labour is the key in bean production due to the fact that it is labour intensive and the crop is delicate and needs care, especially 
Table 4 Effects of productive resources on bean production

\begin{tabular}{|c|c|c|c|c|c|c|}
\hline Source & SS & $d f$ & MS & Number of Obs. & $=$ & 225 \\
\hline Model & $11,070,595$ & 10 & $1,107,059$ & Prob $>F$ & $=$ & 0 \\
\hline \multirow{3}{*}{ Residual } & $19,939,303$ & 214 & $93,174.31$ & $R^{2}$ & $=$ & 0.357 \\
\hline & & & & Adj $R^{2}$ & $=$ & 0.327 \\
\hline & Coef. & SE & $t$ & $p>t$ & {$[95 \% \mathrm{Cl}]$} & \\
\hline Sex of respondent ( $1=$ male; $0=$ female) & 78.85395 & 46.11763 & 1.71 & 0.089 & -12.049 & 169.7569 \\
\hline If head of household head can read and write $(1=y e s ; 0=$ no $)$ & 40.74894 & 108.4455 & 0.38 & 0.707 & -173.009 & 254.5072 \\
\hline If used improved seed $(1=$ yes; $0=$ no) & -66.4666 & 48.31498 & -1.38 & 0.17 & -161.701 & 28.76759 \\
\hline If used fertilizer on beans ( $1=$ yes; $0=$ no) & 167.6574 & 56.48232 & 2.97 & 0.003 & 56.32443 & 278.9903 \\
\hline If used pesticides, fungicides, herbicides $(1=$ yes; $0=$ no) & 199.804 & 55.34028 & 3.61 & 0 & 90.72211 & 308.8858 \\
\hline If used hired labour on beans $(1=$ yes; $0=$ no $)$ & 62.65897 & 92.66948 & 0.68 & 0.5 & -120.003 & 245.3208 \\
\hline Annual income & 0.001043 & 0.000196 & 5.32 & 0 & 0.000656 & 0.001429 \\
\hline Proportion of land allocated to beans & 220.7884 & 81.88656 & 2.7 & 0.008 & 59.38088 & 382.1959 \\
\hline If own ox plough ( $1=$ yes; $0=$ no) & -28.9785 & 42.45408 & -0.68 & 0.496 & -112.66 & 54.70318 \\
\hline Number of information sources & -25.458 & 17.43061 & -1.46 & 0.146 & -59.8156 & 8.899722 \\
\hline
\end{tabular}

during weeding. Another variable which was significant was proportion of land allocated to bean production (0.008). Research findings show that land is the most important household asset for households that depend on agriculture for their livelihoods. Birachi et al. [3] found out that land size influences bean production in Burundi with elasticity of 0.323 . This infers an elastic response to bean production; thus, a unit increase in land would increase production by $32 \%$. This concurs with Allendorf [1] that improving women's access to land and security of tenure has direct impacts on farm productivity and can also have far-reaching implications for improving household welfare. Bigger sizes of land under bean production could mean higher yields and eventually higher incomes. Women farmers need more access to land and other productive resources in order to secure livelihoods and food production for their families. However, according to FAO, women have access to only about $20 \%$ of all land worldwide, with their allotments generally of smaller size and lower quality [10]. The more land allocated for bean production, the higher the household incomes from crop sales, all other variables being constant. This concurs with a study by Takulder [16] in Bangladesh that found out that the size of household land had a positive effect on household incomes.

Annual income from cropping was highly significant and influenced bean production in the 4 counties. This could mean that households with higher incomes from sale of crop produce ploughed back some money to bean production. This money could have bought improved certified seed, fertilizers, chemicals and farm equipment. According to a SNV brief [15], women farmers often have to negotiate or even pay to access productive resources, which are mainly owned by men or controlled by maledominated authorities. In many communities, gender disparities with regard to land and other productive resources are linked to assumptions that men, as heads of households, control and manage land-subliminally reflecting ideas that women are unable to manage productive resources such as land effectively, that productive resources given to women are "lost to another family" in the event of marriage, divorce or (male) death and that men will provide for women's financial security [4].

Table 5 presents the correlation between quantity of beans harvested per season per household and other variables. The results indicate that there was a positive correlation between quantity of beans harvested and land

Table 5 Factors affecting bean production in the selected counties

\begin{tabular}{|c|c|c|c|c|}
\hline Variable & Coefficient & SE & $t$ value & $p$ value \\
\hline Sex of household head & -88.04712 & 43.85819 & -2.01 & $0.046^{* * *}$ \\
\hline Literacy level of household head & -46.50036 & 115.8537 & -0.40 & 0.689 \\
\hline Annual income from crop farming & 0.0003993 & 0.0001754 & 2.28 & $0.024^{* * *}$ \\
\hline Proportion of land used for crop & 79.41412 & 12.25358 & 6.48 & $0.000 * * *$ \\
\hline Number of market information sources & 12.26448 & 18.28571 & 0.67 & 0.503 \\
\hline
\end{tabular}


under crops and annual income from crops. This could be explained by the assumption that the more the income, more money is invested in bean production in purchasing inputs and paying labour for weeding, harvesting and storage, all other variables remaining constant. On the other hand, there is a weak negative correlation between the sex of household head and quantity of beans harvested. Male-headed households tended to harvest more quantities than female-headed ones. This could be attributed to the fact that majority of male farmers use farm inputs which help increase yields and productivity.

\section{Conclusions and implications of the study}

Demographic results showed that most of the farmers were aged between 41 and 58 years. There is need to involve the youth in bean production, but this can only be possible if the production is commercialized because the youth want to engage in money-making ventures. Majority of the respondents were married; hence, interventions should target both husband and wife for improved bean production. It is important to note that all the respondents were the farmers involved in bean production. As much as the households were headed by men, $68 \%$ of the respondents were women who are the major bean producers. This implies that for improved bean production this group needs to be targeted.

It is also clear that access and control of resources is the very key in crop production in this case beans. Some of the resources found statistically significant were land under crops, access and use of fertilizer and annual household incomes from crops. The more land a family allocated to bean production, the higher the quantities harvested. The implication is that farmers both men and women need sensitization on the importance of equitable access and control of productive resources in bean production. Education level though not significant is important because literate farmers tend to apply skills learned better than the illiterate ones. They tend to adopt new technologies faster. Farm input use was low in all counties; hence there is a need for training farmers on good agricultural practices. Fertilizer and storage pesticides use was very minimal, hence leading to low productivity and loss of bean grain, respectively. More male-headed households owned important farm equipment compared to female-headed households. Gender of household head was strongly correlated with bean production with male-headed households producing higher quantities than the female-headed ones. In two counties, femaleheaded households did not use some key farm inputs like fertilizer, fungicides and storage pesticides. Most female-headed households did not own an ox plough which is the very key in land preparation for bean production. Lack of it could mean late planting, resulting in low quantities harvested. This is a gap that needs to be addressed.

\section{Recommendation}

There is a need to come up with interventions which will benefit the men, women and youth to avoid disharmony in the households. Commercialization of bean production and processing should be gender responsive. There is need for capacity building for men, women and youth farmers on good agricultural practices to fill the gap on farm input use, post-harvest practices and agribusiness skills improved productivity. Farmers need to be trained on gender issues, especially on importance equal access and control of resources. Commercialization of the bean crop can be promoted by engaging processors and other value chain actors who will add value to beans and eventually create demand for the bean grain. One way of bringing together the value chain actors is forming a bean stakeholders platform which would comprise farmers, input dealers, transporters, aggregators, traders and service providers. Ownership of farm equipment which affects productivity was very low in female-headed households; hence there is a gap which needs to be filled. This could be done through linking women to credit providers and coming up with affordable collateral so that they can access and afford the services. For policy makers, there is a need to subsidize farm inputs like fertilizers and farm chemicals.

\section{Abbreviations \\ CAPI: Computer-Assisted Personal Interviewing; KALRO: Kenya Agricultural and Livestock Research Organization; CIAT: International Centre for Tropical Agriculture; IDRC: International Development Research Centre; NARO: National Agricultural Research Organization. \\ Authors' contributions \\ AG and JK helped in data collection, EB and MM helped in data analysis, and EB, MU, DK and JN reviewed the paper internally. All authors read and approved the final manuscript. \\ Author details \\ ${ }^{1}$ Kenya Agricultural and Livestock Research Organization (KALRO), P.O Box 57811-00200, Nairobi, Kenya. ${ }^{2}$ International Centre for Tropical Agricul- ture, Nairobi, Kenya. ${ }^{3}$ International Development Research Centre (IDRC), Nairobi, Kenya. ${ }^{4}$ National Agricultural Research Organization (NARO), Kampala, Uganda.}

\section{Acknowledgements}

I would like to acknowledge Collins Odhiambo who helped with plagiarism check and the team of enumerators who helped with data collection.

\section{Competing interests}

The authors declare that they have no competing interests.

\section{Availability of data and material}

The datasets used and or analysed during the current study are available from the corresponding author on reasonable request.

Consent for publication

Consent for publication was given by a representative of the respondents 


\section{Ethics approval and consent to participate}

KALRO is a government research organization whose researchers are allowed to carry out surveys without seeking for approval. The respondents agreed to being interviewed and did not need to sign anything.

\section{Funding}

The research was funded by IDRC and ACIAR. Design, data collection, analysis and interpretation were carried out by the research scientists.

\section{Publisher's Note}

Springer Nature remains neutral with regard to jurisdictional claims in published maps and institutional affiliations.

Received: 7 July 2017 Accepted: 10 November 2018 Published online: 22 November 2018

\section{References}

1. Allendorf K. Do women's land rights promote empowerment and child health in Nepal? World Dev. 2007;35(11):1975-88.

2. Ariga J, Jayne TS, Kibaara B, Nyoro JK. Trends and patterns in fertilizer use by smallholder farmers in Kenya, 1997-2007. Njoro: Tegemeo Institute of Agricultural Policy and Development, Egerton University; 2009.

3. Birachi EA, Ochieng J, Wozemba D, Ruraduma C, Niyuhire MC, Ochieng D. Factors influencing small holder farmers' bean production and supply to market in Burundi. Afr Crop Sci J. 2011;19(4):335-42.

4. Canadian HIV/AIDS Legal Network. Respect, protect and fulfill: legislating for women's rights in the context of HIV/AIDS, vol. two, family and property issues; 2009.

5. CIAT. Impact of improved bean varieties in Western Kenya, highlights. No. 18; December 2004.

6. CIAT. Bean disease and pest identification and management, hand book for small-scale seed producers. ISSN 2220-3370, Uganda; 2010.
7. Department for International Development. Gender equality at the heart of development: why the role of women is crucial to ending world poverty. London: DFID; 2007.

8. Food Agricultural Organization. Gender mainstreaming in forestry in Africa. Regional Report. Rome; 2007.

9. Food Agricultural Organization. The state of food and agriculture; 2009.

10. Food Agricultural Organization. Gender and land rights: understanding complexities, adjusting policies; Economic and social perspectives. FAO Policy Brief, Rome; 2010

11. Food Agricultural Organization. Status of food and agriculture, Rome; 2011.

12. Langat HK (2016) Social cultural factors influencing women's participation in food security programs among households in Bomet County, Kenya.

13. Palacios-Lopez A, Christiaensen L, Kilic T. How much of the labour in African agriculture is provided by women? Food Policy. 2017.

14. PABRA. Bean corridors: a novel approach to scale up national and regional trade in Africa. Nairobi: Pan-Africa Bean Research Alliance (PABRA); 2017.

15. SNV Practice Brief. Gender and agriculture; 2012

16. Takulder D. Assessing determinants of income of rural households in Bangladesh. J Appl Econ Bus Res. 2014;4(2):80-106.

17. Thamaga-Chitja JM, Hendriks SL, Ortmann GF, Green M. Impact of maize storage on rural household food security in Northern Kwazulu-Natal. J Fam Ecol Consum Sci. 2004:32:8-15.

18. Waithaka MM, Thornton PK, Shepherd KD, Ndiwa NN. Factors affecting the use of fertilizers and manure by smallholders: the case of Vihiga, western Kenya. Nitrogen Cycle Agro Ecosyst. 2007;78:211-24.

19. Wiredu AN, Gyasi KO, Marfo KA, Asuming-Brempong S, Haleegoah J, Asuming Boakye A, Nsiah BF. Impact of improved varieties on the yield of rice producing households in Ghana. In: Second Africa rice congress, Bamako, Mali, 22-26 March; 2010.

20. World Bank. World Development Report 2008. Agriculture for development. Washington, DC; 2007.
Ready to submit your research? Choose BMC and benefit from:

- fast, convenient online submission

- thorough peer review by experienced researchers in your field

- rapid publication on acceptance

- support for research data, including large and complex data types

- gold Open Access which fosters wider collaboration and increased citations

- maximum visibility for your research: over $100 \mathrm{M}$ website views per year

At $\mathrm{BMC}$, research is always in progress.

Learn more biomedcentral.com/submissions 